\title{
PEMANFAATAN HASIL HUTAN BUKAN KAYU (HHBK) PENGHASIL KERAJINAN TANGAN ANYAMAN OLEH MASYARAKAT DESA PANGKALAN BUTON KECAMATAN SUKADANA KABUPATEN KAYONG UTARA
}

(The Utilization of non wood forest products (HHBK) produced woven by commuities at Pangkalan Village Boton Sub-District Sukadana Kayong Utara District)

\author{
Dahyanti, Gusti Hardiansyah, dan Lolyta sisillia \\ Fakultas Kehutanan Universitas Tanjungpura Jalan Imam Bonjol Pontianak. 78124 \\ Email: dahyantimahira@gmail.com
}

\begin{abstract}
Utilization of non-wood products for woven crafts isone of the pottentials in Pangkalan Buton Village, Sukadana Subdistrict, North Kayong Regency and becomes a raw material in making woven crafts. The research aims to obtain types of non-wood forest products for woven handicrafts and to describe the types of woven handicraft products by the people of Pangkalan Buton Village, Sukadana District. Research using descriptive qualitative methods. Data Collection is done by intetview, observation, and documentation. The results showed that there are 6 types of plants that are used by the community for woven crafts, namely bamboo rope (Gigantochloa apus), coconut (Cocos nucifera), nipah (Nypa fruticans), pandanus thorn (Pandanus tectoris) recam (Distranopteris linearis) and rattan candles (Calamus javensis). These types of planys are used as raw materials for woven crafts. Bamboo Reeds are into baskets and mistaken products. Coconut leaves are made into rattan products. Nipah leaf is made intoa woven roofing product. Pandan thom leaves are made into woven products for table mats, wallets, bags, pencil cases, tissues and mats. Resam rod is made into woven ring and bracelet products. Rattan rods are made into woven basket and cupboard products.

Keybord: Non wood forest product, Types of plants, Woven crafts product, Utilization.
\end{abstract}

\section{PENDAHULUAN}

Menurut UU Kehutanan Nomor 41 tahun 1999, disebutkan bahwa hasil hutan bukan kayu (HHBK) adalah hasil hutan hayati maupun non hayati. HHBK adalah hasil hutan hayati baik nabati maupun hewani beserta produk turunan dan budidayanya kecuali kayu yang berasal dari hutan (Permenhut 35/Menhut-II/2007. Pemanfaatan HHBK di Indonesia sudah sejak lama dilakukan oleh penduduk di sekitar hutan untuk memenuhi kebutuhan hidup sehari-hari. Oleh karena itu, HHBK tidak dapat diabaikan begitu saja karena
HHBK menjadi salah satu peluang yang tepat untuk dikembangkan dan hal itu tentu saja dapat mengurangi tingkat ketergantungan masyarakat terhadap hasil hutan kayu. Menurut penelitian Njuramana dan Butarbutar (2008), masyarakat di Timor Barat memanfaatakan kemiri, asam, madu, seedlak, kulit kayu manis, minyak kayu putih, minyak gaharu, dan minyak cendana. Simanjuntak et al. (2017) menyatakan masyarakat di Dusun Parit Pangeran Desa Tanjung Saleh Kecamatan Sungai Kakap Kabupaten 
Kubu Raya memanfaatakan hasil hutan, kepiting dan tumbuhan mangrove dari hutan mangrove yang berada di sekitar desa. Menurut penelitian Christien $d k k$ (2013) ada 20 produk HHBK yang dimanfaatkan masyarakat disekitar hutan Desa Minanga III di Kabupaten Minahasa Tenggara.

Pemanfaatan HHBK di Provinsi Kalimantan Barat oleh masyarakat disekitar hutan digunakan untuk kebutuhan hidup sehari-hari. Pada umumnya masyarakat Desa Pangkalan Buton sebagian besar penduduknya masih memenuhi kebutuhan hidup mereka dengan menjual hasil anyaman yang terbuat dari bambu tali, kelapa, nipah, pandan duri, resam, dan rotan lilin. Contoh produk-produk kerajinan anyaman yang ada di Desa Pangkalan Buton adalah bakul, nyiru, sarang ketupat, atap rumah, alas meja, dompet, tas, tempat pensil, tempat tissu, tikar, cincin, gelang, keranjang, dan lemari. Kajian mengenai pemanfaatan HHBK untuk kerajinan tangan anyaman oleh masyarakat di Desa Pangkalan Buton, Kecamatan Sukadana, Kabupaten Kayong Utara belum banyak mendapatkan perhatian yang lebih serius dan hingga saat ini belum ada data informasi tentang jenis-jenis HHBK untuk kerajinan tangan anyaman, pemanfaatan, dan pengolahan oleh masyarakat Desa Pangkalan Buton tersebut. Tujuan penelitian ini adalah memperoleh jenis-jenis HHBK kerajinan tangan anyaman, dan mendeskripsikan jenis-jenis produk kerajinan tangan anyaman yang dimanfaatkan pengrajin Desa Pangkalan Buton. Oleh karena itu, perlu adanya penelitian lebih lanjut untuk mendapatkan informasi terhadap pemanfaatan HHBK kerajinan tangan anyaman bagi masyarakat di Desa Pangkalan Buton Kecamatan Sukadana Kabupaten Kayong Utara.

\section{METODE PENELITIAN}

Penelitian ini dilakukan di Desa Pangkalan Buton Kecamatan Sukadana Kabupaten Kayong Utara. Waktu penelitian dilaksanakan selama \pm 4 (empat) minggu dimulai pada tanggal 1 Juni sampai 1 Juli 2019. Objek penelitian ini adalah masyarakat yang memanfaatkan HHBK untuk kerajinan tangan anyaman di Desa Pangkalan Buton Kecamatan Sukadana Kabupaten Kayong Utara. Penelitian ini menggunakan metode survey. Pemilihan responden menggunakan teknik Purposive sampling yaitu semua masyarakat pengrajin dijadikan responen sebanyak 93 pengrajin kerajinan tangan anyaman. Teknik pengambilan data melalui wawancara dengan dibantu daftar pertanyaan. Analisis data dalam penelitian ini adalah analisis deskriptif yang digunakan untuk memperoleh jenisjenis HHBK untuk kerajinan tangan anyaman dan mendeskripsikan jenisjenis produk kerajinan tangan anyaman berdasarkan hasil wawancara, observasi, dan dokumentasi yang dilakukan terhadap responden.

\section{HASIL DAN PEMBAHASAN}




\section{A. Jenis-jenis Hasil Hutan Bukan} Kayu Penghasil Kerajinan Tangan Anyaman

Pemanfaatan HHBK untuk kerajinan tangan anyaman yaitu bambu tali, kelapa, nipah, pandan duri, resam, dan rotan lilin. Adapun produk yang dihasilkan seperti bakul, nyiru, sarang ketupat, atap rumah, alas meja, dompet, tas, tempat pensil, tempat tissu, tikar, cincin, gelang, keranjang dan lemari. Hasil wawancara mengenai pemanfaatan dari HHBK untuk kerajinan tangan anyaman kepada masyarakat Desa Pangkalan Buton dapat dilihat pada Tabel 1 .

Tabel 1. Jenis-jenis Hasil Hutan Bukan Kayu untuk Kerajinan Tangan Anyaman (Types of Non Wood Forest Product for Woven Crafts)

\begin{tabular}{|c|c|c|c|c|c|c|}
\hline No & Nama Lokal & Nama Ilmiah & $\begin{array}{l}\text { Buku } \\
\text { Identifikasi }\end{array}$ & Famili & $\begin{array}{l}\text { Bagian } \\
\text { yang } \\
\text { digunakan }\end{array}$ & $\begin{array}{l}\text { Jenis } \\
\text { Anyaman }\end{array}$ \\
\hline 1. & Bambu tali Nyiru & Gigantochloa apus & (Andri Thomas) & Poaceae & Batang & Bakul \\
\hline 2. & Kelapa & Cocos nucifera & (Andri Thomas) & Areacaceae & Daun & $\begin{array}{l}\text { Sarang } \\
\text { Ketupat }\end{array}$ \\
\hline & Nipah & Nypa fruticans & (Andri Thomas) & Areacaceae & Daun & Atap rumah \\
\hline 4. & Pandan duri & Pandanus tectoris & (Andri Thomas) & Panddanacea & Daun & $\begin{array}{l}\text { Alas meja, } \\
\text { Dompet, Tas, } \\
\text { Tempat } \\
\text { Pensil, } \\
\text { Tempat Tisu, } \\
\text { Tikar }\end{array}$ \\
\hline 5 . & Resam & $\begin{array}{l}\text { Distranopteris } \\
\text { linearis }\end{array}$ & (Andri Thomas) & Gleicheniaceae & Batang & $\begin{array}{l}\text { Cincin, } \\
\text { Gelang }\end{array}$ \\
\hline 6. & Rotan lilin & Calamus javensis & (Andri Thomas) & Areacaceae & Batang & $\begin{array}{l}\text { Keranjang, } \\
\text { Lemari }\end{array}$ \\
\hline
\end{tabular}

Pembuatan kerajinan tangan anyaman oleh masyarakat Desa Pangkalan Buton tergantung kebutuhan atau bersifat insidentil dan tergantung pemesanan. Hasil kerajinan yang dibuat sebagian untuk pemakaian pribadi sebagian juga untuk diproduksi namun produk yang dijual tidak secara besarbesaran.

\section{B. Produk Kerajinan Anyaman Bambu Tali}

1. Bakul

Bakul merupakan sebuah wadah yang biasanya dibuat dari serat-serat tanaman yang dianyam. Pada bagian atasnya bisa terbuka atau ditutup dengan sebuah penutup. Bakul berbentuk bulat dengan panjang $28 \mathrm{~cm}$, lebar $25 \mathrm{~cm}$, dan punya gagang dan biasanya digunakan sebagai tempat beras. Pemanfaatan bambu sebagai bahan baku bakul ini dilakukan oleh masyarakat dengan aktivitas perdagangan bakul yang terbuat dari batang bambu di lokasi penelitian Desa Pangkalan Buton telah banyak ditemukan. Harga jual beli bakul yang terbuat dari bambu, sekisaran $\mathrm{Rp}$ 10.000-15.000 yang berukuran kecil sampai sedang. Masyarakat Desa Pangakalan Buton mengolah bakul jika ada pemesanan, lama pembuatan bakul 
sekitar 3-4 hari untuk satu bakul dari proses pengambilan bahan sampai proses akhir penganyaman.

2. Nyiru

Nyiru atau tampi beras yang biasanya di sebut masyarakat Desa Pangkalan Buton ini yaitu alat dapur tradisonal yang terbuat dari anyaman bambu tali. Bentuk bundar dengan diameter antara 36 hingga $70 \mathrm{~cm}$. Pada bagian tepi diberi lapisan irisan bambu melingkar atau di daerah Kayong Utara dikenal dengan nama ganggang, lebar dari ganggang sekitar 3-5 cm, mungkin nama nyiru atau tampi di masyarakat lain mempunyai istilah yang berbeda. Tampi atau nyiru dikatakan tradisional, karena dibuat secara manual, menggunakan keterampilan tangan tanpa bantuan mesin. Harga alat dapur ini relatif murah sekitar Rp. 15.000 35.000 tergantung besar kecilnya ukuran tampi. Ada yang berukuran kecil, sedang, dan besar. Di Desa Pangkalan Buton masih memproduksi alat dapur ini terutama bagi masyarakat yang pekerjaannya sebagai petani biasanya masyarakat menggunakan tampi beras untuk membersihkan beras yang masih bercampur dengan kotoran, atau dedak ataupun berupa kerikil, kemudian masyarakat menjual beras yang sudah bersih tersebut. Sampai saat ini, tampi masih banyak dijumpai di masyarakat termasuk di daerah Kayong Utara tepatnya di Desa Pangkalan Buton, lama pembuatan nyiru dari bambu ini kurang lebih 7 hari dari proses pengambilan bahan, pemotongan dan pembelahan buluh bambu, penjemuran buluh bambu dan proses penganyaman. Produk-produk kerajinan anyaman bambu sebagai bahan anyaman bakul dan nyiru dapat terlihat pada Gambar 1.

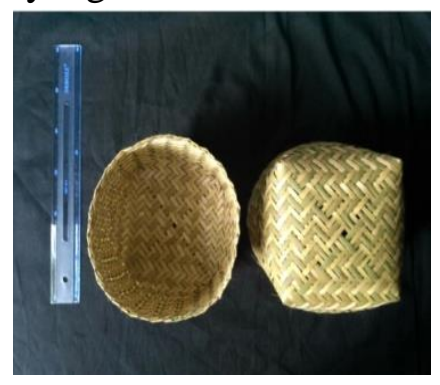

a. Anyaman Bakul

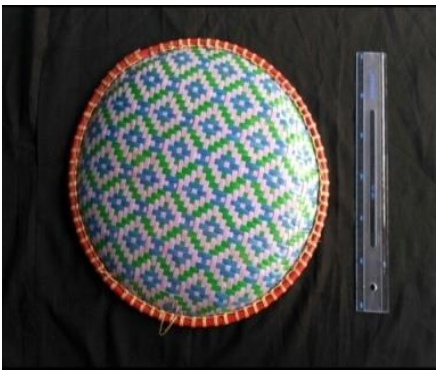

b. Anyaman Nyiru

\section{Gambar 1. Produk Anyaman Bambu Tali di Desa Pangkalan Buton (Bamboo Woven Crafts Products in Pangkalan Buton Village)}

Pengambilan bahan baku untuk kerajinan anyaman bambu tidak jauh dari rumah. Pemanfaatan Bambu sebagai bahan kerajinan anyaman bakul dan nyiru ini banyak dimanfaatkan masyarakat Desa Pangkalan Buton dikarenakan menganyam ini sudah menjadi turun temurun dari nenek moyang kemudian bakul dan nyiru juga merupakan salah satu harganya terjangkau dan dengan ketahanan bambu tali ini bisa mencapai 3-5. Hal ini didukung dengan hasil penelitian Linda (2017). 


\section{Produk Kerajinan Anyaman Kelapa}

Pemanfaatan kelapa oleh Masyarakat Desa Pangkalan Buton yaitu berbentuk anyaman yang menggunakan daun kelapa yang masih muda. Bentuk ketupat persegi panjang yang dinamakan dengan ketupat pasar. Menganyam ketupat sudah menjadi tradisi masyarakat Desa Pangkalan Buton. Ketupat merupakan menu khas lebaran ala melayu di Kabupaten Kayong Utara. Menu ini setiap tahun mudah ditemui di rumah-rumah warga Melayu Kayong Utara, baik saat idul fitri maupun idul adha. Terkadang juga menjadi tradisi pula pada acara syukuran ataupun selamatan tertentu dan ada juga untuk kepentingan bisnis. Pemanfaatan daun kelapa sebagai bahan baku untuk membuat ketupat ini dilakukan oleh ibu-ibu rumah tangga yang kemudian mereka jual dengan masyarakat yang telah memasan. Harga jual beli anyaman ketupat yang terbuat dari daun kelapa, sekisaran Rp 500-1.000 untuk satu ketupat dengan panjang dan lebar 6-8 cm tergantung panjang daun kelapa.

Pengolahan atau cara pembuatan sarang ketupat dari daun kelapa ini juga sama dengan hasil penelitian yang dilakukan oleh Santi, dkk (2015) cara pembuatannya dengan cara dilitkan yang dilakukan di Desa Batu Buil Kecamatan Belimbing Kabupaten Melawi. Pohon kelapa sendiri banyak dimanfaatkan masyarakat Desa Pangkalan buton antara lain buah kelapa untuk dikonsumsi, mayang nipah untuk pengobatan, namun yang berpotensi dan yang umum dimanfaatkan masyarakat yaitu daun kelapa dapat dimanfaatkan sebagai kerajianan tangan anyaman. Pemanfaatan daun kelapa untuk kerajinan tangan dimanfaatkan saat hari raya dan acara selamatan lainnya, untuk jenis produk yang dihasilkan belum banyak padahal jika dimanfaatkan mempunyai nilai jual serta menambah penghasilan masyarakat sekitar

\section{Produk Kerajinan Anyaman Nipah}

Pemanfaatan nipah oleh Masyarakat Desa Pangkalan Buton dalam bentuk anyaman yang terbuat dari daun nipah. Pemanfaatan daun nipah ini berupa produk anyaman atap rumah. Pengambilan dan pembuatan atap daun nipah di Desa Pangkalan Buton yaitu sesuai pesanan konsumen, dan pengambilan daun nipah menggunakan karung $50 \mathrm{~kg}$, dalam 1 karung mendapatkan 10-13 keping atap. Pemanfaatan daun nipah sebagai atap rumah ini banyak dimanfaatkan masyarakat Desa Pangkalan Buton dikarenakan harganya terjangkau dan dengan ketahanan nipah bisa mencapai 3-5 tahun ketahanan atap ini sebagai bahan baku bangunan. Menurut penelitian Hendri (2009) menyatakan bahwa kategori yang digunakan masyarakat untuk pengrajin anyaman atap rumah dengan daun bertahan 3 sampai 5 tahun. Atap dari daun nipah sangat baik untuk melindungi rumah dari cuaca panas dan daun nipah baik untuk kebutuhan bahan bangunan seperti atap sebgagai genteng dan dinding bangunan. Hal ini di dukung dengan penelitian Arta, dkk (2015).

Pengolahan atau cara pembuatan atap daun nipah ini juga sama dengan hasil penelitian yang dilakukan oleh Suparto (2019). Di Dusun Suka Maju Desa Sungai 
Sepeti Kecamatan Seponti Kabupaten Kayong Utara, dengan pembuatan atap daun nipah disusun kemudian di jahit. Atap yang sudah jadi akan dijual sesuai pesanan dengan harga jual yaitu Rp 2.5003.000 /keping. Pohon nipah sendiri dari daun dapat dimanfaatkan sebagai kerajinan tangan untuk saat ini di Desa Pangkalan Buton sendiri itu kurang dimanfaatkan masyarakat sekitar, padahal jika dimanfaatkan mempunyai nilai jual serta menambah penghasilan masyarakatsekitar, serta kuranya dukungan dalam pengolahan.

\section{E. Produk Kerajinan Anyaman Pandan.}

1. Alas meja

Jenis pandan yang digunakan untuk alas meja yaitu jenis pandan duri. Bentuk alas meja persegi panjang, digunakan sebagai alas meja makan dan biasanya diletakkan di meja ruang tamu. Harga jual beli alas meja yang terbuat dari pandan, sekisaran Rp 40.000 yang berukuran kecil sampai besar dengan panjang ukuran 65 $\mathrm{cm}$, lebar $50 \mathrm{~cm}$ untuk keranjang ukuran besar panjang $75 \mathrm{~cm}$, lebar $60 \mathrm{~cm}$. Masyarakat Desa Pangakalan Buton membuat alas meja ini jika ada pemesanan, lama pembuatan alas meja dari pandan duri kurang lebih 2-3 hari.

\section{Dompet}

Jenis pandan yang digunakan untuk dompet yaitu jenis pandan duri. Bentuk dompet persegi panjang, fungsi sebuah dompet adalah untuk menyimpan barang yang sangat penting. Pemanfaatan pandan sebagai bahan baku dompet ini dilakukan oleh masyarakat dengan dengan menjualnya. Harga jual dompet yang terbuat dari pandan, sekisaran Rp 15.00030.000 tergantung motif dari dompet jika motifnya lebih rumit maka harga jual lebih mahal dengan panjang ukuran $18 \mathrm{~cm}$, lebar $11 \mathrm{~cm}$. Masyarakat Desa Pangakalan Buton membuat dompet ini jika ada pemesanan, lama pembuatan dompet dari pandan duri kurang lebih 3-5 hari.

3. Tas

Jenis pandan yang digunakan untuk tas yaitu jenis pandan duri. Bentuk tas segi empat, dipakai untuk menaruh, menyimpan, dan membawa sesuatu. Pemanfaatan pandan sebagai bahan baku tas ini sudah sejak dulu digunakan masyarakat Desa Pangkalan Buton namun seiring berjalannya waktu kini perkembangannya lebih bervariasi sehingga masyarakat lebih menggunakan tas hasil olahan dari kulit hewan, kain dan lain-lain akan tetapi para pengrajin khusunya di Desa Pangkalan Buton tetap memproduksi hasil produk anyamannya dengan menjualnya. Biasanya para pengrajin memasarkan anyaman tas mereka kesalah satu tempat pasar yang tidak jauh dari kediaman para pengrajin. Harga jual beli tas yang terbuat dari pandan, sekisaran $\mathrm{Rp}$ 50.000-70.000 tergatung jenis motif dari tas tas tersebut, untuk ukuran besar panjang $40 \mathrm{~cm}$, lebar $35 \mathrm{~cm}$ untuk ukuran kecil panjang $30 \mathrm{~cm}$, lebar $26 \mathrm{~cm}$. Masyarakat Desa Pangakalan Buton membuat tas ini jika ada pemesan, lama pembuatan tas dari pandan duri kurang lebih 7-14 hari

4. Tempat pensil

Jenis pandan yang digunakan untuk tempat pensil yaitu jenis pandan duri. Bentuk tempat pensil persegi panjang, 
digunakan untuk meyimpan suatu alat tulis sehingga tersimpan dengan rapih. Pemanfaatan pandan sebagai bahan baku tempat pensil ini lumayan banyak diminati terutama bagi anak-anak yang duduk di sekolah baik itu SD, SMP, SMA, bahkan masyarakat yang berkerja di salah satu kantor dan lain-lain. Masyarakat banyak membeli produk hasil anyaman pandan ini karena bentuknya yang unik, harganya yang murah dan tahan lama. Harga jual beli dompet yang terbuat dari pandan, sekisaran Rp 10.000 sampai Rp 25.000 yang berukuran kecil sampai besar dengan panjang ukuran $19 \mathrm{~cm}$, lebar $9 \mathrm{~cm}$. Masyarakat Desa Pangakalan Buton membuat tempat pensil jika ada pemesanan, lama pembuatan alas meja dari pandan duri kurang lebih 2-3 hari.

5. Tempat tissu

Tempat tissu merupakan anyaman yang biasanya terbuat dari pandan duri. Bentuk tissu persegi panjang, digunakan sebagai tempat tissu dan biasanya diletakkan di meja makan dan ruang tamu. Masyarakat Desa Pangakalan Buton masih menggunakan tempat tissu dari anyaman pandan karena masyarakat berpendapat bahwa tempat tissu dari anyaman pandan memiliki model yang unik dan tahan lama perawatan mudah bahan daun pandan kesan natural. Jenis pandan yang digunakan yaitu jenis pandan duri. Bentuk tempat tissu persegi panjang, dapat dijadikan sebagai penyimpan tissu, hiasan rumah, hiasan dinding, hiasan kantor, hiasan hotel. Pemanfaatan pandan sebagai bahan baku tempat tissu ini sudah sejak dulu digunakan masyarakat Desa Pangkalan Buton namun seiring berjalannya waktu kini perkembangannya lebih bervariasi sehingga masyarakat lebih menggunakan tempat pensil olahan dari kayu, plastik dan lain-lain akan tetapi para pengrajin khusunya di Desa Pangkalan Buton tetap memproduksi hasil produk anyamannya dengan menjualnya. Biasanya para pengrajin memasarkan anyaman tempat tissu mereka kesalah satu tempat pasar yang tidak jauh dari kediaman para pengrajin. Harga jual beli tempat tissu yang terbuat dari pandan, sekisaran Rp 22.000 dengan ukuran panjang $20 \mathrm{~cm}$, lebar $15 \mathrm{~cm}$. Masyarakat Desa Pangakalan Buton membuat tempat tissu ini jika ada pemesan, lama pembuatan tas dari pandan duri kurang lebih 2-3 hari.

6. Tikar

Jenis pandan yang digunakan untuk tikar yaitu jenis pandan duri. Bentuk tikar persegi panjang, tikar pandan sejak dulu digunakan untuk alas makan, alas duduk dalam acara perkawinan, alas untuk jemur padi dan alas untuk tidur. Anyaman tikar pandan yang terkenal di Kayong Utara yaitu motif pucuk rebung. Pucung rebung merupakan salah satu anyaman tikar pandan yang sangat populer hingga saat ini dalam masyarakat melayu di Tanah Kayong. Motif ini melambangkan kehidupan baru yang akan tumbuh dan bermanfaat bagi orang lain. Melalui dorongan tradisi tersebut beberapa kelompok masyarakat masih tetap membuat anyaman pandan hinga saat ini. Hal ini juga didukung oleh sumber bahan baku pandan yang masih melimpah di Kabupaten Kayong Utara. Akan tetapi, tidak bisa dielakan karena perkembangan 
teknologi, tikar pandan mulai ditinggalkan oleh masyarakat pada umunnya, sebagai contoh tikar plastik dianggap lebih diterima pasar dibanding tikar pandan tentunya karena tikar plastik lebih tahan lama dan lebih tahan air dibandingkan tikar pandan. Namun para pengrajin khusunya di Desa Pangkalan Buton masih memepertahankan budaya dan tradisi ini tetap berkarya dan mengembangkan anyaman tikar pandan untuk disesuaikan dengan situasi pasar saat ini. Pemanfaatan pandan sebagai bahan baku tikar ini masih tetap diproduksi oleh masyarakat Desa Pangkalan Buton. Harga jual beli tikar yang terbuat dari pandan, sekisaran $\mathrm{Rp}$ 65.000-110.000 yang berukuran sedang

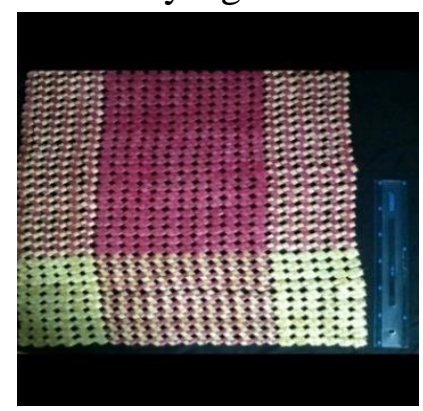

a. Alas meja

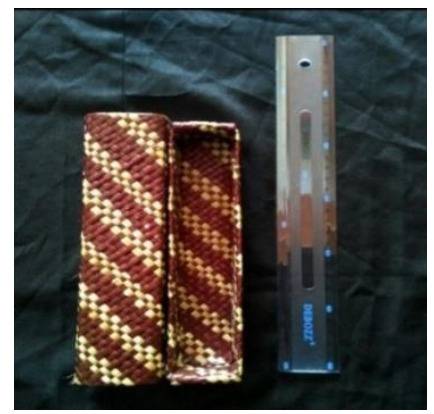

d. Tempat pensil

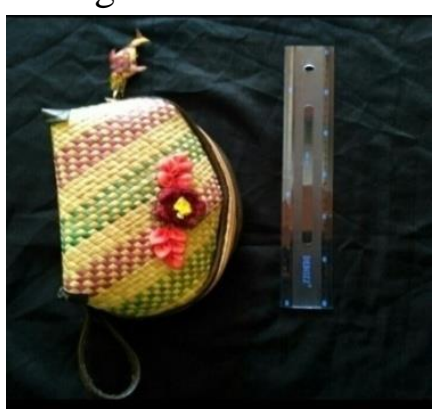

b. Dompet

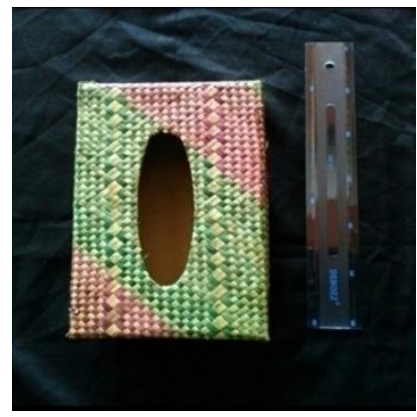

e. Tempat tissu

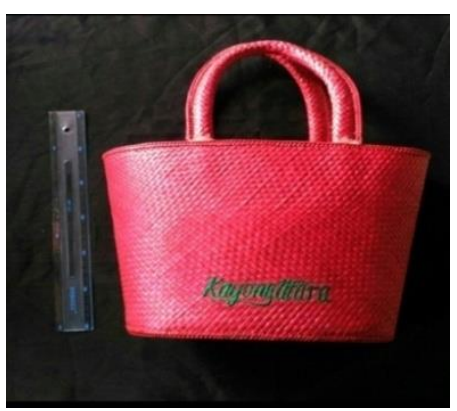

c. Tas

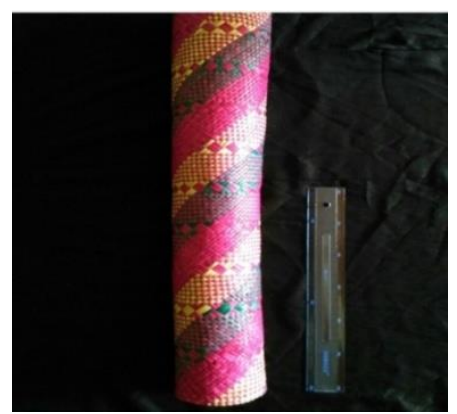

f. Tikar

Gambar 2. Produk Anyaman Pandan di Desa Pangkalan Buton (Pandan Woven Crafts Product in Pangkalan Buton Village)

Pengambilan bahan baku untuk bahan yang sudah siap diolah. Pengolahan anyaman pandan ini cukup jauh dan atau cara pembuatan anyaman daun biasanya para pengrajin langsung membeli pandan ini juga sama dengan hasil 
penelitian yang dilakukan oleh Nggadas (2019) dengan proses pengambilan daun pandan, pembuangan duri sampai proses penganyaman. Tumbuhan pandan sendiri dari daun dapat dimanfaatkan sebagai kerajinan tangan untuk saat ini di Desa Pangkalan Buton sendiri masih dimanfaatkan namun untuk mendapatkan bahan dasarnya mengalami kesulitan, padahal dari segi pemesanan sampai saat ini masih terus berjalan.

\section{F. Produk Kerajinan Anyaman Resam}

Pemanfaatan resam sebagai bahan baku cincin dan gelang ini masih tetap diproduksi oleh masyarakat Desa

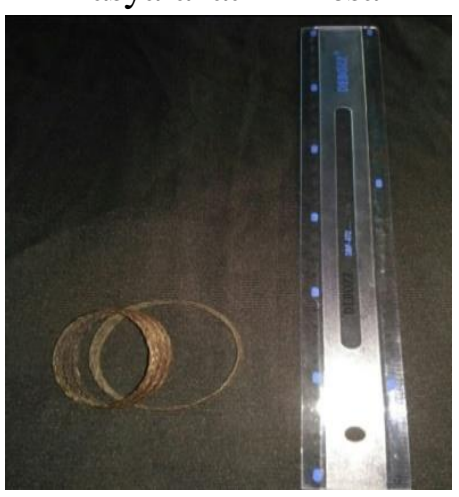

a. Cincin resam
Pangkalan Buton. Harga jual beli cincin dan gelang yang terbuat dari resam, untuk anyaman cincin resam sekisaran $\mathrm{Rp}$ 10.000 yang berukuran kecil dengan diameter $3 \mathrm{~cm}$ untuk cincin yang berukuran besar sekisaran Rp. 15.000 dengan diameter $5 \mathrm{~cm}$. Sedangkan untuk anyaman gelang resam sekisaran $\mathrm{Rp}$. 15.000 yang berukuran kecil dengan diameter $7 \mathrm{~cm}$, untuk gelang yang berukuran besar sekisaran Rp.30.000 dengan diameter $10 \mathrm{~cm}$. Produk-produk anyaman resam dapat dilihat pada Gambar 3.

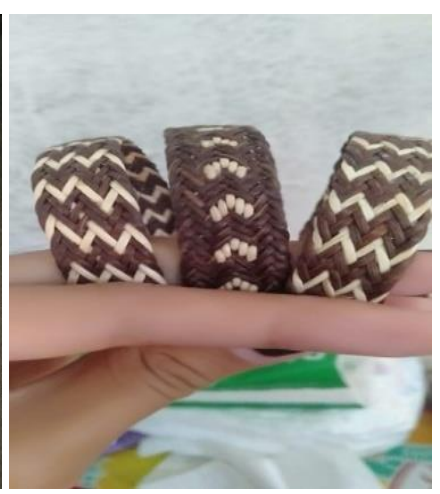

b. Gelang resam

\section{Gambar 3. Produk Anyaman Resam di Desa Pangkalan Buton (Resam Woven Crafts Product in Pangkalan Buton Village)}

Pada penelitian Hartanto (2015) Cara pengolahan hampir sama dengan Masyarakat Desa Pangkalan Buton Kecamatan Sukadana Kabupaten Kayong Utara, cara pengolahanya dari proses pengambilan batang, merayut kulit, menjemur hasil rawutan dan proses penganyaman. Masyarakat Desa Pangakalan Buton membuat aksesoris resam ini jika ada pemesanan. Untuk pengambilan bahan bakunya para pengrajin mengambil bahan yang ada didekat rumah namun, ada juga yang membeli bahan yang sudah siap dianyam, lama pembuatan gelang resam dari pandan ini yaitu memakan waktu sekitar 1-2 hari untuk 1 cincin dan gelang. Meskipun proses membuatnya tidak begitu lama tetapi harga jualnya lumayan mahal ini dikarenakan bentuk atau motif anyaman nya yang lumayan rumit.

G. Produk Kerajinan Anyaman Rotan Lilin

1. Keranjang 
Keranjang merupakan anyaman yang terbuat dari rotan lilin. Bentuk anyaman rotan ini oval yang memiliki gagang dan bisa digunakan sebagai tempat buah. Keranjang ini memiliki variasi yang di anyam dengan rotan dan bawahnya terbuat dari triplek. Pemanfaatan rotan sebagai bahan baku keranjang ini dilakukan oleh masyarakat dengan aktivitas perdagangan keranjang yang terbuat dari batang rotan di lokasi penelitian Desa Pangkalan Buton telah banyak ditemukan. Harga jual beli keranjang yang terbuat dari rotan, sekisaran Rp 35.000-50.000 yang berukuran kecil sampai sedang. Untuk ukuran besar sekisaran Rp. 50.00070.000 dengan panjang ukuran sedang 50 $\mathrm{cm}$, lebar $45 \mathrm{~cm}$ untuk keranjang ukuran besar panjang $65-55 \mathrm{~cm}$. Masyarakat Desa Pangakalan Buton mengolah keranjang jika ada pemesanan, lama pembuatan keranjang dari rotan kurang lebih 7-14 hari dari proses pengambilan bahan sampai proses akhir penganyaman.

2. Lemari

Lemari merupakan anyaman yang terbuat dari rotan lilin. Lemari tersebut berbentuk persegi panjang mempunyai 6 kaki dan 3 tingkat yang biasanya

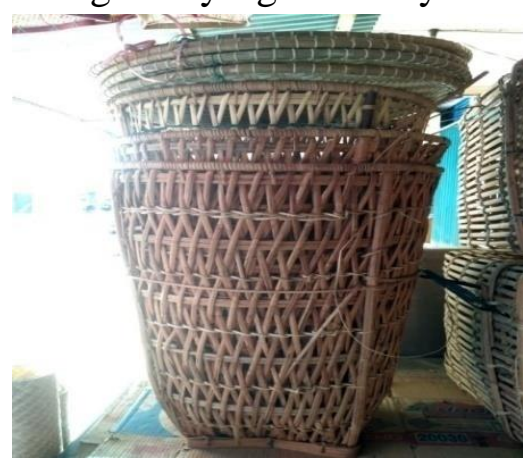

a. Keranjang dari batang rotan digunakan sebagai tempat pakaian. Lemari dipermis agar memiliki warna yang mengkilat. Pemanfaatan rotan sebagai bahan baku lemari ini dilakukan oleh masyarakat dengan aktivitas perdagangan lemari yang terbuat dari batang rotan di lokasi penelitian Desa Pangkalan Buton telah banyak ditemukan. Harga jual beli lemari yang terbuat dari rotan, sekisaran Rp 85.000-130.000 satu lemari rotan dengan panjang $125 \mathrm{~cm}$, lebar $65 \mathrm{~cm}$. Masyarakat Desa Pangakalan Buton mengolah lemari sama halnya dengan keranjang jika ada pemesanan, lama pembuatan lemari dari rotan kurang lebih dari 15 hari dari proses pengambilan bahan sampai proses akhir penganyaman.

Pemanfaatan rotan sebagai bahan kerajinan anyaman keranjang dan lemari ini banyak dimanfaatkan masyarakat Desa Pangkalan Buton dikarenakan harganya terjangkau dan dengan ketahanan rotan ini juga bisa mencapai 4-5 tahun ketahanan keranjang dan lemari ini sebagai bahan baku kerajinan. Hal ini didukung dengan hasil penelitian Simanjuntak (2016). Produk-produk kerajinan anyaman rotan sebagai bahan anyaman keranjang dan lemari dapat dilihat pada gambar 4 .

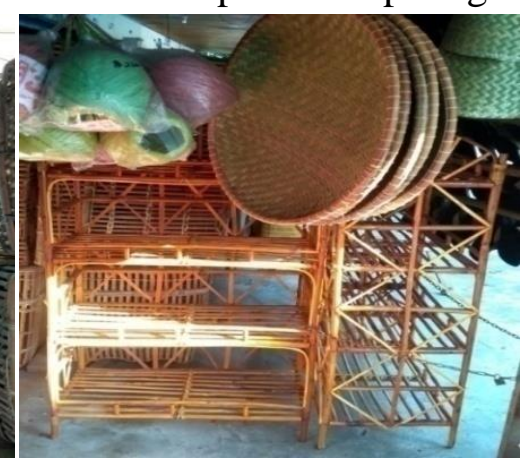

b. Lemari dari batang rotan

Gambar 4. Produk Anyaman Rotan Lilin di Desa Pangkalan Buton (Rattan Candle Woven Crafts Product in Pangkalan Buton Village) 
Pengambilan bahan baku untuk anyaman rotan ini tidak jauh dari rumah. Pada penelitian Simanjuntak (2016) yang telah dilaksanakan di Desa Sedahan Jaya Kecamatan Sukadana Kabupaten Kayong Utara, cara pengolahan hampir sama dengan Masyarakat Desa Pangkalan Buton Kecamatan Sukadana Kabupaten Kayong Utara. Dari awal sampai akhir pengolahan. Namun, untuk produk yang dihasilkan tidak sama dengan penelitian Nggadas (2019) masyarakat Desa Gunam tumbuhan rotan dimanfaatkan untuk membuat nakin dan kursi.

\section{KESIMPULAN}

1. Jenis-jenis hasil hutan bukan kayu (HHBK) yang dimanfaatkan oleh masyarakat Desa Pangakalan Buton untuk kerajinan tangan anyaman sebanyak 6 jenis yaitu tanaman bambu tali, kelapa, nipah, pandan, resam, dan rotan lilin.

2. Jenis-jenis Produk anyaman yang dihasilkan oleh masyarakat Desa Pangkalan Buton sebanyak 14 produk yaitu produk anyaman dari bambu lilin yaitu bakul, dan nyiru, produk anyaman kelapa yaitu anyaman ketupat, produk anyaman nipah yaitu anyaman atap rumah, produk anyaman pandan duri yaitu alas meja, dompet, tas, tempat pensil, tempat tissu, dan tikar, produk anyaman resam yaitu cincin dan gelang, produk anyaman rotan lilin yaitu keranjang dan lemari.

\section{SARAN}

Perlu dilakukan penelitian lebih lanjut tentang jenis-jenis hasil hutan bukan kayu tidak hanya dimanfaatkan sebagai kerajinan anyaman tetapi bisa dimanfaatkan untuk tumbuhan pangan, obat-obatan, dan zat warna dari tumbuhan hasil hutan bukan kayu khusunya di Desa Pangkalan Buton.

\section{DAFTAR PUSTAKA}

Arta, PT, Defri, Y dan M. Mardiansyah. 2015. Minat Masyarakat Desa Lubuk Muda Kecamatan Siak Kecil Kabupaten Bengkalis Terhadap Pemanfaatan Nira Nipah (Nypa fruticans Wurmb ) Sebagai Bahan Baku Bioetanol Untuk Alternatif Bahan Bakar. JOM FAPERTA. Vol. 2 No. 2

Christien N. Kendek, J.S. Tasirin, R. P. Kainde, J. I. Kalangi. 2013. Pemanfaatan Hasil Hutan Bukan Kayu oleh Masyarakat Sekitar Hutan Desa Minanga III Kabupaten Minahasa Tenggara. Jurnal Fakultas Pertanian Universitas Sam Ratulangi Manado.Vol 3, No.5 (2013), Hal 2

Linda, F. 2017. Pemanfaatan Rotan dan Bambu Yang Bernilai Ekonomis oleh Masyarakat Suku Dayak Kanayant di Kecamatan Sengah Terlina Kabupaten Landak. Jurnal Protobiant. Vol 6. (3) : 233-239

Nggadas, A. 2019. Studi Etnobotani Dayak Ribun dalam Pemanfaatan Tumbuhan Bernilai Seni di Desa Gunam Kecamatan Parindu Kabupaten Sanggau. Jurnal Hutan Lestari. Vol 7(2):682-696

Njuramana, G. N. D. dan T. Butarbutar. 2008. Prospek Pengembangan Hasil Hutan Bukan Kayu Berbasis Agroforestry untuk Peningkatan dan Diversifikasi Pendapatan Masyarakat di Timor Barat. Jurnal Info Hutan. V(1):53-62.

Santi, N., Riza, L., Irwan, L. 2015. Pemanfaatan Tumbuhan Arecaceae 
JURNAL HUTAN LESTARI (2019)

Vol. 7 (4) : 1512 - 1523

( Palem Paleman) Oleh Masyarakat Dayak Randu' Di Desa Batu Buil Kecamatan Belimbing Kabupaten Melawi. Jurnal Protobiont. Vol. 4(1) : 128-135

Simanjuntak, N. 2016. Pemanfaatan Rotan Sebagai Bahan Kerajinan Anyaman di Desa Sedahan Jaya Kecamatan Sukadana Kabupaten Kayong Utara. Jurnal Hutan Lestari. Vol 4(3): 344351

Suparto, 2019. Pemanfaatan Nipah (Nypa frutican Wurmb) Di Dusun Suka Maju Desa Sungai Sepeti Kecamatan Seponti Kabupaten Kayong Utara. Jurnal Hutan Lestari. Vol. 7 (1) : 229-236.

Thomas, Andri. 2012. Buku Identifikasi Tumbuhan. Bandung: ALFABETA 